\title{
Bacteria associated to human saliva are major microbial components of Ecuadorian indigenous beers (chicha)
}

Ana L. Freire, Sonia Zapata, Juan Mosquera, Maria Lorena Mejia, Gabriel Trueba

Indigenous beers ( chicha) are part of the indigenous culture in Ecuador. The fermentation process of these beers rely probably on microorganisms from: fermenting substrates, environment and human microbiota. We analyzed the microbiota of artisanal beers (including a type of beer produced after chewing boiled cassava) using bacterial culture and 16S-based tag-encoded FLX amplicon pyrosequencing (bTEFAP). Surprisingly, we found that Streptococcus salivarius and $\mathrm{S}$ treptococcus mutans (part of the human oral microbiota) where among the most abundant bacteria in chewed cassava and in nonchewed cassava beers. We also demonstrated that S. salivarius and S. mutans (isolated from these beers) could proliferate in cassava mush. Lactobacillus sp. was predominantly present in most types of Ecuadorian chicha[i]. $d @ P$ 
1

2

3

4

5 Trueba $^{1}$

$6{ }^{1}$ Instituto de Microbiología, Universidad San Francisco de Quito, Quito, Ecuador.

7

8 Subjects: Food Microbiology, Anthropology

9 Keywords: Lactic acid bacteria, indigenous beer, fermentation, cassava, chicha, Ecuador, mutans, fermented cassava, lactic acid bacteria, saliva, chewed indigenous beer

12

13 Corresponding autor: Gabriel Trueba, gtrueba@usfq.edu.ec 


\section{ABSTRACT}

Indigenous beers (chicha) are part of the indigenous culture in Ecuador. The fermentation process of these beers rely probably on microorganisms from: fermenting substrates, environment

17 and human microbiota. We analyzed the microbiota of artisanal beers (including a type of beer

18 produced after chewing boiled cassava) using bacterial culture and 16S-based tag-encoded FLX

19 amplicon pyrosequencing (bTEFAP). Surprisingly, we found that Streptococcus salivarius and

20 Streptococcus mutans (part of the human oral microbiota) where among the most abundant

21 bacteria in chewed cassava and in non-chewed cassava beers. We also demonstrated that $S$.

22 salivarius and S. mutans (isolated from these beers) could proliferate in cassava mush.

23 Lactobacillus sp. was predominantly present in most types of Ecuadorian chicha. 


\section{INTRODUCTION}

The domestication of fermenting bacteria and yeast predated the domestication of animals and plants; ancestral hominids adapted to metabolize alcohol long time before the Neolithic period (Carrigan et al., 2015). The organoleptic and psychotropic effects associated with the consumption of accidentally fermented fruits or cereals may have motivated early humans to replicate this process. Additionally, fermentation may have provided unintended benefits as fermenting bacteria may have reduced the risks of foodborne diseases in ancient societies (Nakamura et al., 2012; Lewus et al., 1991; Fooks \& Gibson, 2002; Tesfaye et al., 2011); it is still unclear whether these microorganisms confer additional health benefits (McNulty NP, 2011). The use of alcoholic beverages has played a crucial role in the evolution of human societies (Joffe, 1998), nevertheless, very little is known about the process of domestication and evolution of these fermenting microorganisms (Libkinda, et al., 2011).

Many fermenting microorganisms have originated in the environment and food substrates (Martini, 1993), others resemble microorganisms found in the human microbiome suggesting human (skin or intestine) origins (Agapakis \& Tolaas, 2012); in fact some modern fermented dairy products contain intestinal bacteria (Walter, 2008).

Indigenous people from South America (such as Ecuador) prepare a type of beer known as chicha which is made with either corn, boiled cassava or the fruit of the palm Bactris gasipaes (chonta); some cassava beers include an additional chewing step before the fermentation process. A recent report showed that bacteria present in chewed cassava beers were mainly Lactobacillus sp (Colehour, et al., 2014). We analyzed the microbial diversity (using culture dependent and culture independent techniques) in different types of Ecuadorian chicha. 


\section{MATERIALS \& METHODS}

\section{Sample collection}

Four samples of chicha (indigenous beer) from two geographical regions of Ecuador (Andean and Amazon regions) were collected. These samples included beer made with both chewed cassava $(\mathrm{CC})$, mushed cassava $(\mathrm{MC})$; mushed chonta $(\mathrm{CB})$ and ground corn $(\mathrm{CoB})$ (Table 1). The samples of $\mathrm{CC}$ and $\mathrm{MC}$ were purchased from the same household. All these products were obtained from rural communities. None of these beers were pasteurized, nor had they any commercial additives or preservatives. All samples were refrigerated ( 2 to $8^{\circ} \mathrm{C}$ ) after collection; a $2 \mathrm{~mL}$ aliquot of sample was stored at $-20^{\circ} \mathrm{C}$, for molecular phylotyping.

\section{Plate count of lactic acid bacteria (LAB)}

A $20 \mathrm{~mL}$ aliquot of each sample was homogenized in $180 \mathrm{~mL}$ of a sodium citrate solution $\left(10^{-1}\right.$ dilution $)$ and ten-fold dilutions were made in saline solution $(\mathrm{NaCl} 0.9 \%)$. One $\mathrm{mL}$ of each dilution was inoculated in MRS ( $\mathrm{pH} 5$ ) and M17 ( $\mathrm{pH} 7,0.5 \%$ dextrose) by pour plate method. Two incubation temperatures were used $\left(37^{\circ} \mathrm{C}\right.$ and $\left.43^{\circ} \mathrm{C}\right)$ under aerobic and anaerobic conditions, for 3 to 5 days. The incubation time varied because of the different bacteria present on each product.

\section{Phenotypic characterization}

Ten colonies (showing different morphology) were randomly picked from MRS plates from each sample. A subset of colonies showing characteristics of lactic acid bacteria (oxidase negative, catalase negative, Gram positive rods or cocci) was selected for molecular characterization (Table 2); 5 from $\mathrm{CC}, 6$ from $\mathrm{MC}, 6$ from $\mathrm{CB}$ and 8 from $\mathrm{CoB}$. Strains were stored at $-20^{\circ} \mathrm{C}$ in MRS or M17 broth with $20 \%$ of glycerol.

\section{Genotypic characterization of bacterial colonies}


following manufacturer instructions and the DNA was stored at $-20^{\circ} \mathrm{C}$ until used. The $16 \mathrm{~S}$

ribosomal gene was amplified in 25ul containing: $1 \mathrm{X}$ PCR buffer, $2.5 \mathrm{mM} \mathrm{MgCl}_{2}, 0.25 \mathrm{mM}$

dNTP's, 0.2uM 27F primer (5'-AGAGTTTGATCCTGGCTCAG-3'), 0.2uM 1492R primer (5'-

GGTTACCTTGTTACGACTT-3') (Martin, et al., 2001 ), 0.5U GoTaq Flexi DNA polymerase

(Promega, Madison), 5uL of sample DNA and Milli-Q water. The times and temperatures used for the amplification were: melting $\left(94^{\circ} \mathrm{C}, 1\right.$ minute), annealing $\left(56^{\circ} \mathrm{C}, 30\right.$ seconds $)$, elongation $\left(72^{\circ} \mathrm{C}\right.$, 30 seconds), this routine was repeated for 30 cycles, and final extension $\left(72^{\circ} \mathrm{C}, 10\right.$ minutes).

Amplicons were subjected to gel electrophoresis (1\% agarose gel), sequenced at Functional

Biosciences (Madison, WI) and DNA sequences analyzed using Seqmatch (Ribosomal Database

Project http://rdp.cme.msu.edu/) and submitted to GenBank; the accession numbers are:

81

KT722809 to KT722833).

\section{High throughput sequencing analysis}

In order to complement the culture-based protocols, we investigated the microbial diversity using FLX amplicon pyrosequencing. DNA was extracted from all beer samples using DNeasy Plant Mini kit (Qiagen) following manufacturer's protocols, but instead of using AE buffer for elution, we used same volume of PCR Milli-Q water. DNA samples from four types of beer were sent to CD Genomics (NY, USA), for 16S-based phylotyping. DNA was subjected to bacterial tag-encoded FLX amplicon pyrosequencing (bTEFAP) using primers 939F5’TTGACGGGGGCCCGCAC3' and 1492R-5'TACCTTGTTACGACTT3'. For fungal sequences we used ITSF- 5'CTTGGTCATTTAGAGGAAGTAA3'. Resulting sequences (minimum length $=250$ nucleotides) were trimmed and quality scored using USearch (http://drive5.com/); chimeras were detected using UCHIIME (http://drive5.com/) in de novo 
93 mode and were compared using BLASTn to a ribosomal database. Identity values were used to

94 make assignments to the appropriate taxonomic levels: greater than $97 \%$ identity were resolved

95 at the species level and between $95 \%$ and $97 \%$ at the genus level. The number of bacterial

96 sequences we obtained were: 2,965 readings for $\mathrm{CC}, 3,320$ for $\mathrm{MC}, 3,046$ for $\mathrm{CB}$ and 15,623 for

97 CoB. For fungi we obtained 6,763 readings from $\mathrm{CC}, 6,925$ from $\mathrm{MC}$ and 6,558 from $\mathrm{CB}$. We

98 did not carry out fungi analysis of CoB. All sequences were submitted to Sequence Read Archive

99 and accession numbers are: SRP070493, SRS1299611, SRX1612367,SRR3202831,

100 SRS1299612, SRX1612366, SRR3202830, SRS1299613, SRX1612365, SRR3202829,

101 SRS1310202, SRX1600290, SRR3187397, SRS1310203, SRX1600289, SRR3187396,

102 SRS1310204, SRX1600288, SRR3187395, SRS1310207, SRX1612364, SRR3202828,

103 SRS1310208, SRX1600292, and SRR3202832.

104

\section{Streptococcus salivarius and Streptococcus mutans growth in cassava solution}

To rule out the possibility of $S$. salivarius or $S$. mutans contamination, one colony of a pure

separately. Subsequently, $1 \mathrm{~mL}$ of this cell suspension was used to inoculate tubes containing $9 \mathrm{~mL}$

of sterile (autoclaved) chewed cassava solution $(10 \%)$ and incubated at $37^{\circ} \mathrm{C}$ under anaerobic conditions. A $100 \mu \mathrm{L}$ aliquot from each incubated tube was extracted and plated in M17 (this was

to determine the ability of these bacteria to grow in chewed cassava solution.

\section{Statistical analysis}

We used Mann-Whitney U test to test whether S. salivarius and $S$. mutans were able to

115 grow in cassava solution. Shannon indices were calculated using the formula $H=-\sum p_{i} \log \left(p_{i}\right), p_{i}$ 
116 being the relative frequency of the abundance of each species found. Principal component analysis

117 (PCA) of the bacterial species and abundance of the four beverages was performed using the 118 software SPSS v21 (IBM Corp, Armonk, NY). 


\section{RESULTS}

\section{Characterization of bacterial isolates}

Twenty-five bacterial isolates (cultured from the 4 beer types) were characterized by $16 \mathrm{~s}$

122 rDNA sequencing showing $99 \%$ to $100 \%$ identity when compared with GenBank sequences (Table

123 2). The predominant bacterial species in all beers were Lactobacillus fermentum (16\%),

124 Lactococcus lactis (16\%), Leuconostoc mesenteroides (16\%), and Streptococcus salivarius (16\%);

125 followed by Lactobacillus plantarum (8\%), Weissella confusa (8\%), Lactobacillus casei (4\%),

126 Lactobacillus pantheris (4\%), Lactobacillus parabuchneri (4\%), Lactobacillus paracasei (4\%)

127 and Streptococcus mutans (4\%). The most diverse bacterial composition (using culture-dependent

128 techniques) found in $\mathrm{CoB}$ (6 bacterial species), followed by the $\mathrm{CC}$ ( 5 bacterial species), $\mathrm{CB}$ (3

129 bacterial species) and MC (2 bacterial species). Intriguingly cassava beers contained human 130 salivary bacteria: both CC and MC, had Streptococcus salivarius while CC had also S. mutans 131 (Table 2).

\section{High throughput sequencing analysis}

The beer with greater diversity was CC (31 bacterial species), followed by CoB (26

bacterial species), CB (21 bacterial species), MC (20 bacterial species). The predominant bacterial species in CC were Lactobacillus spp. (40.9\%) followed by human microbiota bacteria:

Streptococcus salivarius (31.94\%), Streptococcus parasanguinis (5.41 \%), Streptococcus

137 pneumoniae (3.65\%). The most prevalent bacteria in MC were Streptococcus spp. (83\%) followed

138 by Lactococcus sp. (9.32\%); the majority of streptococci have been described as part of the human

139 microbiota: Streptococcus salivarius (65\%), Streptococcus pasteurianus (7.74\%), and

140 Streptococcus parasanguinis (3.47\%). The most prevalent bacteria in CB were Weissella confusa 141 (46\%), Weissella sp. (20\%), and Lactococcus lactis (9\%). The dominant bacteria in CoB were 
142 Weissella sp. (19\%) and Lactobacillus plantarum (12.5\%), Lactococcus garviae (2.76\%)

143 Lactobacillus brevis $(2.5 \%)$ (Table 3). The dominant fungal species present in different beers

144 analyzed was very similar; Saccharomyces cerevisiae was the most abundant comprising $92 \%$ of all

145 the taxa detected (Table 4).

146 Growth of $\boldsymbol{S}$. salivarius and $\boldsymbol{S}$. mutans in cassava solution

147 Streptococcus salivarius (Figure 1) and S. mutans (Figure 2) grew in chewed cassava 148 solution. After 48 hours of culture (S. salivarius) and 72 hours ( $S$. mutans), bacterial counts went 149 down.

150 Diversity estimations

$151 \mathrm{CC}$ was the beverage with the most species diversity $(\mathrm{H}=1.06, \mathrm{E}=0.71)$, followed by $\mathrm{CoB}$ $152(\mathrm{H}=0.94, \mathrm{E}=0.66), \mathrm{CB}(\mathrm{H}=0.71, \mathrm{E}=0.54)$, and $\mathrm{MC}(\mathrm{H}=0.59, \mathrm{E}=0.45)$. The evenness values 153 followed the same pattern and suggest that $\mathrm{CC}$ is also the most heterogeneous in terms of species 154 (Hayek, 2010; Pielou, 1966).

155 Principal component analysis

156 The type of beer (fermenting substrate) accounted for $90.4 \%$ of the bacterial species 157 variability and cassava beers had more similar bacterial composition and abundance than the 158 other types of beer; interestingly $\mathrm{CB}$ and $\mathrm{CoB}$ also showed similarity (Figure 3). 
159

160

161

162

163

164

165

166

167

168

169

170

171

172

173

174

175

176

177 178

179

180

181

\section{DISCUSION}

Our study found higher bacterial diversity in beer that contained human saliva (Tables 2 and 3); therefore, saliva may not only speed up the fermentation process (by providing amylases as suggested by Henkel, 2005) but also may offer an additional bacterial inoculum which may favor this process. This finding may provide additional explanation for the adoption of such a peculiar process in the beer's manufacture.

Our study also demonstrate the presence of oral streptococci such as $S$. salivarius, $S$. mutans, $S$. parasanguinis in cassava beers; these bacteria may thrive on carbohydrates present in the oral cavity after starchy meals (Moye, et al., 2014; Burne, et al., 1998). Oral bacteria $S$. salivarius and $S$. mutans were cultured from cassava chicha (with saliva and without saliva) in large numbers and were shown to grow in mushed cassava under laboratory conditions. Oral bacteria in beer without human saliva may indicate contamination of fermenting containers (or utensils). Fermenting bacteria are known to produce biofilm in containers (Kebede et al., 2007) and both types of cassava beers were obtained from the same household, and probably they use the same pots for both type of beers. It is possible that some strains of $S$. salivarius from these beers may be adapting to the fermentation process; Streptococcus thermophilus, a bacteria used as starter in yogurt (Burton, et al., 2006) may have evolved from S. salivarius (Hols, et al., 2005). Future studies should investigate the prevalence of $S$. salivarius in larger number of cassava chichas from other locations and find out whether the strains of S. salivarius isolated from beers are different from those isolated from human saliva.

A recent study failed to detect $S$. mutans and $S$. salivarius in chicha prepared with chewed cassava in Ecuador (Colehour, et al., 2014). The disagreement between both studies may result from differences in samples in both studies; Colehour, et al., 2014 collected beers that were 
182 fermenting for 4 days while we collected samples that were fermenting for 3 days. Beer microbiota 183 changes overtime (Steinkraus, 2006) and in the case of S. mutans and S. salivarius we observed a 184 sharp increase and decline in bacterial populations in 24 hours (Figures 1 and 2). Unlike Colehour, 185 et al., 2014, we also carried out bacterial cultures. Reduction on streptococci populations may be due to the consumption of all the nutrients,

187 188 accumulation of toxic metabolites, autolysis. (Dufour \& Lévesque, 2013). Also, these bacteria are known to form biofilm (Ajdic, et al., 2002; Li, et al., 2002) which may change bacterial location and reduction of planktonic cells. Additionally, unlike our study Colehour, et al., 2014 found predominance of L. reuteri which is known to antagonize S. salivarius (Nikawa, et al., 2004; Corby, et al., 2005). Similar to previous studies (Colehour, et al., 2014; Elizaquivel, et al., 2010; Puerari, et al., 2015), Lactobacillus was a dominant genus of lactic bacteria in chicha found in both culture dependent and independent assessments.

Our study complements previous microbiological analysis carried out in chicha and shows for the first time the potential adaptation of $S$. salivarius, $S$. mutants (and possibly other streptococci from the human upper respiratory tract) to grow in cassava mush. The study not only shows how bacteria from human microbiota may adapt to artisanal fermentative processes but also shows that chewed chicha may potentially transmit human pathogens such as S. mutans, one of the causative agents of dental plaque and cavities (Loesche, 1986); Streptococcus mutans can be transmitted person to person probably through saliva (Baca et al., 2012). This is especially relevant because these types of beers are consumed as early as 2 or 3 days after preparation.

The main limitation of our study was the low number of samples analyzed of each beer. However this limitation does not invalidate the main findings of this study. Additionally, the 
204 culture medium (MRS) is not suitable to culture Lactobacillus from cereals (Minervini, et al., 205 2012), therefore we may have underestimated the bacterial diversity in these beers. 


\section{ACKNOWLEDGEMENTS} analysis. 


\section{REFERENCES}

Agapakis CM , Tolaas S. 2012. Smelling in multiple dimensions. Current Opinion in Chemical Biology, 16(5):569-575

Ajdić D, McShan WM, McLaughlin RE, Savić G, Chang J, Carson MB, Primeaux C, Tian R, Kenton S, Jia H, Lin S, Qian Y, Li S, Zhu H, Najar F, Lai H, White J, Roe BA, Ferretti JJ. 2002. Genome sequence of Streptococcus mutans UA159, a cariogenic dental pathogen. Proceedings of the National Academy of Sciences, 99(22):14434-14439

Baca P, Castillo AM, Liébana MJ, Castillo F, Martín-Platero A, Liébana J. 2012. Horizontal transmission of Streptococcus mutans in schoolchildren. Medicina Oral, Patologia Oral y Cirugia Bucal 17(3):e495-500

Burne R. 1998. Oral streptococci... products of their environment. Journal of Dental Research 77(3): $445-452$

Burton JP, Wescombe PA, Moore CJ, Chilcott CN, Tagg JR. 2006. Safety assessment of the oral cavity probiotic Streptococcus salivarius K12. Applied and Environmental Microbiology 72(4):3050-3053

Carrigan MA, Uryasev O, Frye CB, Eckman BL, Myers CR, Hurley TD, Benner SA. 2015. Hominids adapted to metabolize ethanol long before human-directed fermentation. Proceedings of the National Academy of Sciences 112(2):458-463.

Colehour AM, Meadow JF, Liebert MA, Cepon-Robins TJ, Gildner TE, Urlacher SS, Bohannan BJ, Snodgrass JJ, Sugiyama LS. 2014. Local domestication of lactic acid bacteria via cassava beer fermentation. PeerJ 8;2:e479. doi:10.7717/peerj.479

Dufour D, Lévesque CM. 2013. Cell death of Streptococcus mutans induced by a quorum-sensing peptide occurs via a conserved streptococcal autolysin. Journal of Bacteriology 195(1):105-114

Elizaquível P, Pérez-Cataluña A, Yépez A, Aristimuño C, Jiménez E, Cocconcelli PS, Vignolo G, Aznar R. 2015. Pyrosequencing vs. culture-dependent approaches to analyze lactic acid bacteria 
associated to chicha, a traditional maize-based fermented beverage from Northwestern Argentina. Internationl Journal of Food Microbiology doi: 10.1016/j.ijfoodmicro.2014.12.027.

Fisher K, Phillips C. 2009. The ecology, epidemiology and virulence of Enterococcus. Microbiology 155(6): 1749-1757

Fooks LJ, Gibson GR. 2002. In vitro investigations of the effect of probiotics and prebiotics on selected human intestinal pathogens. FEMS Microbiology Ecology 39(1):67-75

Hayek LAC, Buzas MA. 2010. Surveying natural populations: quantitative tools for assessing biodiversity. Columbia University Press. USA

Henkel TW. 2005. Parakari, an indigenous fermented beverage using amylolytic Rhizopus in Guyana. Mycologia 97(1):1-11

Hols P, Hancy F, Fontaine L, Grossiord B, Prozzi D, Leblond-Bourget N, Decaris

\section{B, Bolotin A, Delorme C, Dusko Ehrlich S, Guédon E, Monnet V, Renault P,}

Kleerebezem M. 2005. New insights in the molecular biology and physiology of Streptococcus thermophilus revealed by comparative genomics. FEMS Microbiology Reviews 29(3):435-463

Joffe AH.1998. Alcohol and social complexity in ancient western Asia. Current Anthropology 39(3): $297-322$

Kebede A, Viljoen B, Gadaga T, Narvhus J, Lourens-Hattingh A. 2007. The effect of container type on the growth of yeast and lactic acid bacteria during production of Sethemi, South African spontaneously fermented milk. Food Research International, 40(1):33-38

Lewus CB, Kaiser A, Montville TJ. 1991. Inhibition of food-borne bacterial pathogens by bacteriocins from lactic acid bacteria isolated from meat. Applied and Environmental Microbiology 57(6): $1683-1688$ 
260

261

262

263

264

265

266

267

268

269

270

271

272

273

274

275

276

277

278

279

280

281

282

283

284

Li YH, Tang N, Aspiras M B, Lau PC, Lee JH, Ellen RP, Cvitkovitch DG. 2002. A quorum-sensing signaling system essential for genetic competence in Streptococcus mutans is involved in biofilm formation. Journal of Bacteriology 184(10):2699-2708

Libkind D, Hittinger CT, Valério E, Gonçalves C, Dover J, Johnston M,Gonçalves P, Sampaio JP. 2011. Microbe domestication and the identification of the wild genetic stock of lager-brewing yeast. Proceedings of the National Academy of Sciences 108(35):14539-14544

Loesche WJ. 1986. Role of Streptococcus mutans in human dental decay. Microbiological Reviews 50(4):353-380

McNulty NP, Yatsunenko T, Hsiao A, Faith JJ, Muegge BD, Goodman AL, Henrissat B, Oozeer R, Cools-Portier S, Gobert G, Chervaux C, Knights D, Lozupone CA, Knight R, Duncan AE, Bain JR, Muehlbauer MJ, Newgard CB, Heath AC, Gordon JI. 2011. The impact of a consortium of fermented milk strains on the gut microbiome of gnotobiotic mice and monozygotic twins. Scince Translational Medicine 3(106):106ra106. doi: 10.1126/scitranslmed.3002701

Martin-Laurent F, Philippot L, Hallet S, Chaussod R, Germon J, Soulas G, Catroux G. 2001. DNA extraction from soils: old bias for new microbial diversity analysis methods. Applied and Environmental Microbiology 67(5):2354-2359

Martini A. 1993. Origin and domestication of the wine yeast Saccharomyces cerevisiae. Journal of Wine Research 4(3):165-176

Minervini F, Di Cagno R, Lattanzi A, De Angelis M, Antonielli L, Cardinali G, Cappelle S, Gobbetti M. 2012. Lactic acid bacterium and yeast microbiotas of 19 sourdoughs used for traditional/typical italian breads: interactions between ingredients and microbial species diversity. Applied and Environtal Microbiology 78(4):1251-1264

Moye ZD, Zeng L, Burne RA. 2014. Fueling the caries process: carbohydrate metabolism and gene regulation by Streptococcus mutans. Journal of oral Microbiology DOI 10.3402/jom.v6.24878 
285

286

287

288

289

290

291

292

293

294

295

296

297

298

299

300

301

302

303

304

305

306

307
Nakamura S, Kuda T, An C, Kanno T, Takahashi H, Kimura B. 2012. Inhibitory effects of Leuconostoc mesenteroides 1RM3 isolated from narezushi, a fermented fish with rice, on Listeria monocytogenes infection to Caco-2 cells and A/J mice. Anaerobe 18(1):19-24.

\section{Nikawa H, Makihira S, Fukushima H, Nishimura H, Ozaki Y, Ishida K, Darmawan S, Hamada T,} Hara K, Matsumoto A, Takemoto T, Aimi R. 2004. Lactobacillus reuteri in bovine milk fermented decreases the oral carriage of mutans streptococci. International Journal of Food Microbiology 95(2):219-223

Pielou EC. 1966. The measurement of diversity in different types of biological collections. Journal of Theoretical Biology, 13:131-144

Puerari C, Magalhães-Guedes KT, Schwan RF. 2015. Physicochemical and microbiological characterization of chicha, a rice-based fermented beverage produced by Umutina Brazilian Amerindians. Food Microbiology 46:210-217

Steinkraus KH. 2002. Fermentations in world food processing. Comprehensive Reviews in Food Science and Food Safety 1(1):23-32

Tesfaye A, Mehari T, Ashenafi M. 2011. Inhibition of some foodborne pathogens by pure and mixed $\mathrm{LAB}$ cultures during fermentation and storage of Ergo, A traditional Ethiopian fermented milk. ARPN J. Agric. Biolog. Sci, 6(4):13-19.

Walter J. 2008. Ecological role of lactobacilli in the gastrointestinal tract: implications for fundamental and biomedical research. Applied and Environmental Microbiology 74(16): 4985-4996. 


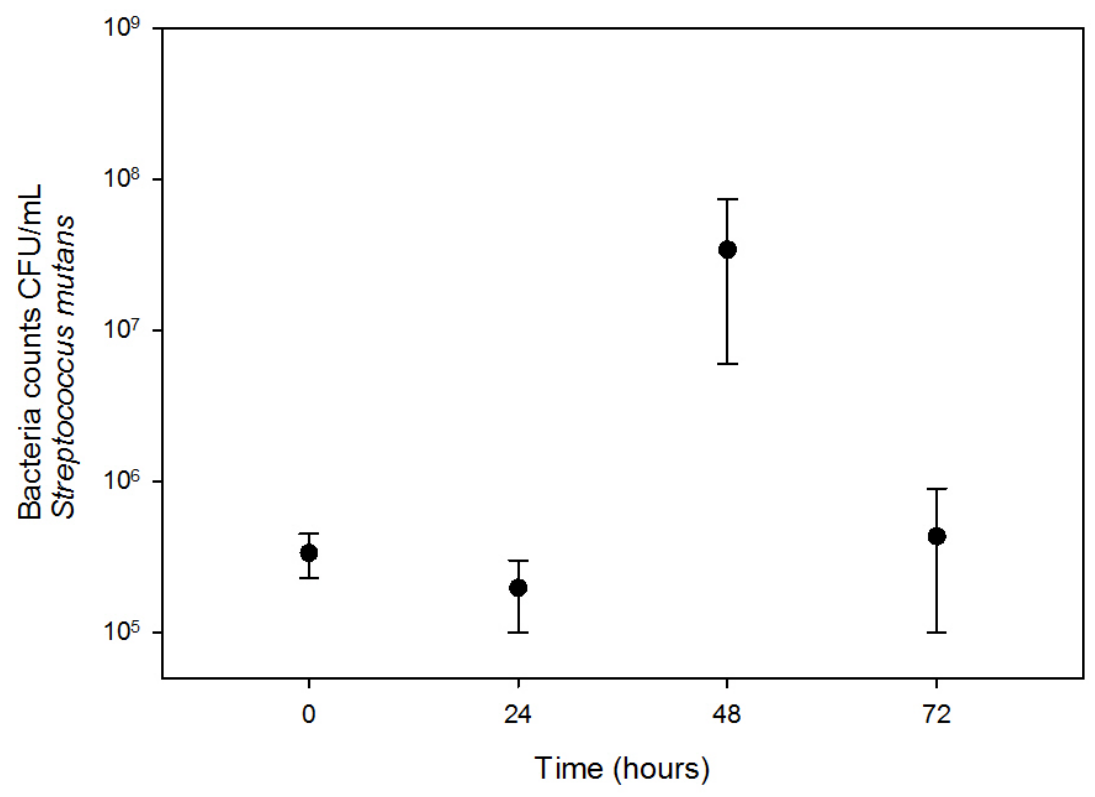

Figure 1. Growth of $\boldsymbol{S}$. salivarius in sterile chewed cassava solution. There is a significant increase in CFU (Mann-Whitney U test) at the 24 hours of incubation compared with those at

312 inoculation time (0 hours). 


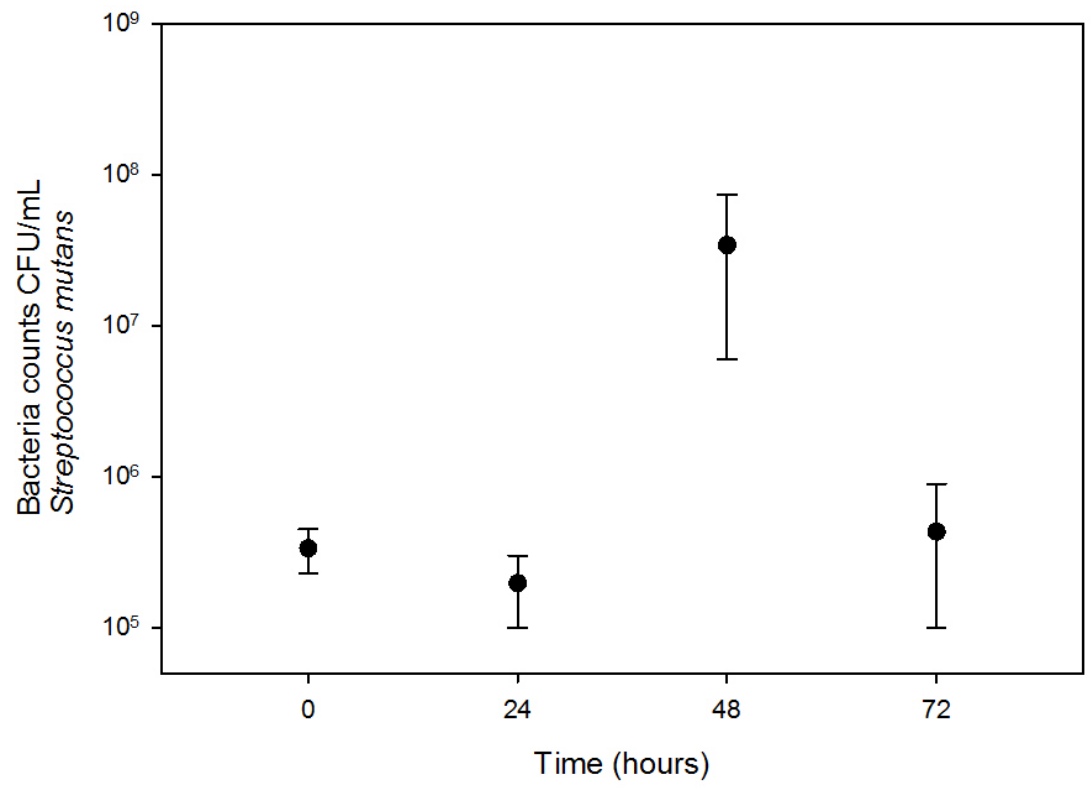

Figure 2. Growth of $\boldsymbol{S}$. mutans in chewed cassava solution. There is a significate increase in

327 time (0 hours). 


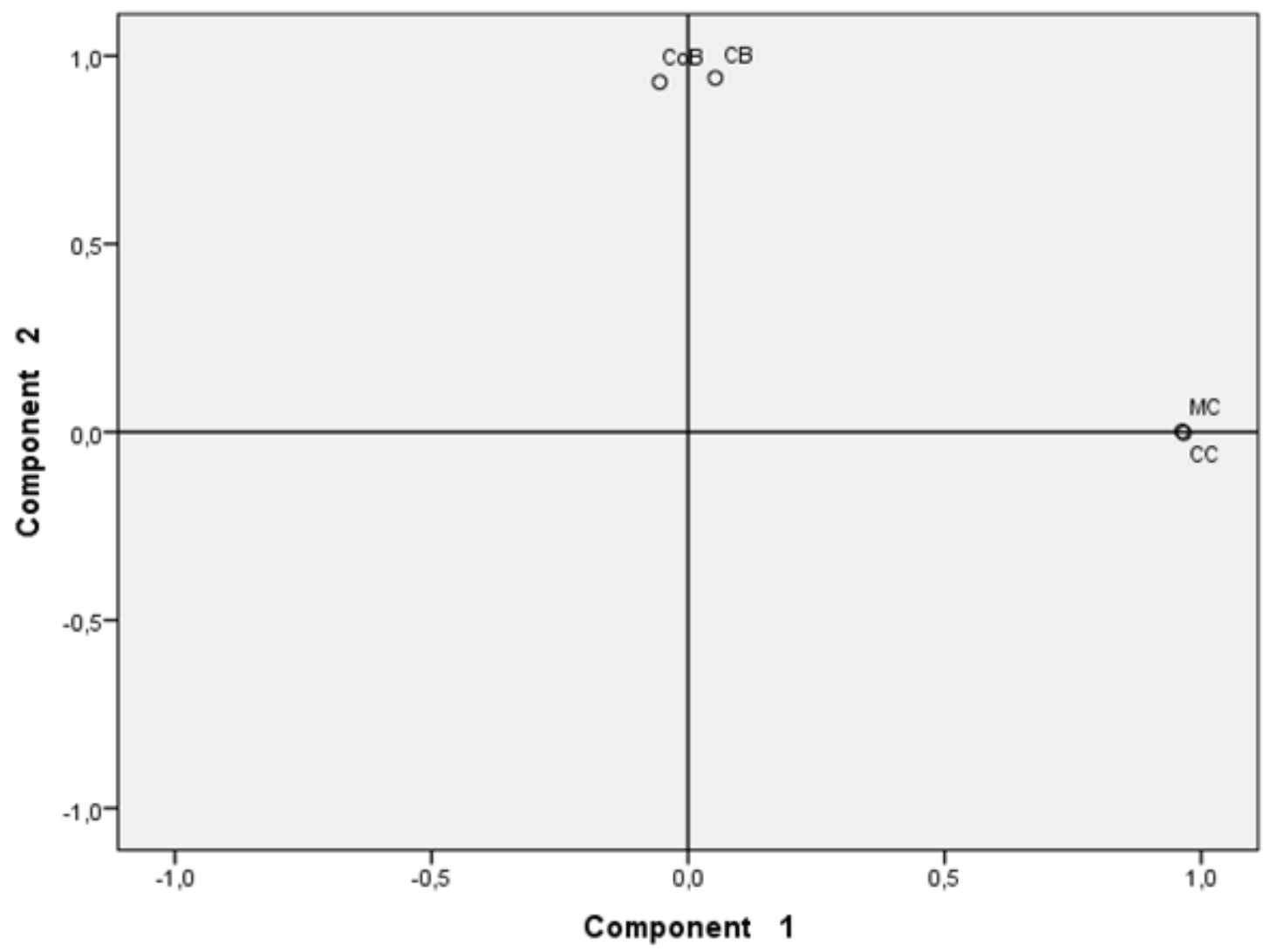

Figure 3. Principal component analysis of beers' microbiota. Beers made with cassava (MC and $\mathrm{CC}$ ) formed a cluster different from the cluster formed by beers made with either chonta (CB) or corn $(\mathrm{CoB})$. Each pair of beverages that form a group share a similar bacterial species profiles and abundance. 
344 Table 1. Description and site of collection of the different types of indigenous beers

345 analyzed.

\begin{tabular}{ccccc}
\hline Main ingredient & $\begin{array}{c}\text { Substrate } \\
\text { Scientific name }\end{array}$ & $\begin{array}{c}\text { Geographic } \\
\text { al region }\end{array}$ & $\begin{array}{c}\text { Site of } \\
\text { collection }\end{array}$ & $\begin{array}{c}\text { Time of } \\
\text { fermentation }\end{array}$ \\
\hline Chewed cassava & Manihot esculenta & Amazon & Puyo & 3 days \\
Mushed cassava & Manihot esculenta & Amazon & Puyo & 3 days \\
Chonta & Bactris gasipaes & Amazon & Tena & 2 days \\
Corn (jora) & Zea mays & Highlands & Pifo & 2 days \\
\hline
\end{tabular}


361 Table 2. Bacteria isolated from the four beer samples. All the 25 strains were obtained by

362 bacterial cultures in MRS and M17 and 16s ribosomal gene from colonies was amplified and

363 sequenced.

364

\begin{tabular}{|c|c|c|c|c|}
\hline Sample & Isolate ID & $\begin{array}{l}\text { Culture } \\
\text { Media }\end{array}$ & $\begin{array}{l}\text { Growth } \\
\text { condition }\end{array}$ & Identification (16S) \\
\hline \multirow{5}{*}{$\begin{array}{c}\text { Chewed } \\
\text { cassava } \\
\text { beer }\end{array}$} & $25 \mathrm{~A} 2$ & MRS & Anaerobic & Leuconostoc mesenteroides \\
\hline & $25 \mathrm{C} 2$ & MRS & Aerobic & Lactobacillus fermentum \\
\hline & $25 \mathrm{E} 2$ & M17 & Anaerobic & Streptococcus mutans \\
\hline & $25 \mathrm{~F} 1$ & M17 & Aerobic & Lactococcus lactis \\
\hline & $25 \mathrm{H} 1$ & M17 & Aerobic & Streptococcus salivarius \\
\hline \multirow{6}{*}{$\begin{array}{c}\text { Mushed } \\
\text { cassava } \\
\text { beer }\end{array}$} & $26 \mathrm{~A} 1$ & MRS & Anaerobic & Lactobacillus fermentum \\
\hline & $26 \mathrm{~B} 1$ & MRS & Anaerobic & Lactobacillus fermentum \\
\hline & $26 \mathrm{C} 2$ & MRS & Aerobic & Lactobacillus fermentum \\
\hline & $26 \mathrm{E} 2$ & M17 & Anaerobic & Streptococcus salivarius \\
\hline & $26 \mathrm{~F} 2$ & M17 & Anaerobic & Streptococcus salivarius \\
\hline & $26 \mathrm{G} 1$ & M17 & Aerobic & Streptococcus salivarius \\
\hline \multirow{6}{*}{$\begin{array}{c}\text { Chonta } \\
\text { beer }\end{array}$} & $27 \mathrm{~A} 1$ & MRS & Anaerobic & Lactobacillus plantarum \\
\hline & $27 \mathrm{~B} 1$ & MRS & Anaerobic & Weissella confusa \\
\hline & $27 \mathrm{C} 1$ & MRS & Aerobic & Weissella confusa \\
\hline & $27 \mathrm{E} 1$ & M17 & Aerobic & Lactococcus lactis \\
\hline & $27 \mathrm{~F} 2$ & M17 & Anaerobic & Lactococcus lactis \\
\hline & $27 \mathrm{G} 2$ & M17 & Aerobic & Lactococcus lactis \\
\hline \multirow[t]{8}{*}{ Corn beer } & $61 \mathrm{~B} 2$ & MRS & Anaerobic & Lactobacillus casei \\
\hline & $61 \mathrm{G} 1$ & M17 & Anaerobic & Leuconostoc mesenteroides \\
\hline & $61 \mathrm{G} 2$ & M17 & Anaerobic & Lactobacillus plantarum \\
\hline & $61 \mathrm{H} 1$ & MRS & Anaerobic & Lactobacillus parabuchneri \\
\hline & $61 \mathrm{I} 1$ & MRS & Anaerobic & Lactobacillus paracasei \\
\hline & $61 \mathrm{~J} 1$ & MRS & Anaerobic & Lactobacillus pantheris \\
\hline & $61 \mathrm{~K} 1$ & M17 & Anaerobic & Leuconostoc mesenteroides \\
\hline & $61 \mathrm{~L} 1$ & M17 & Anaerobic & Leuconostoc mesenteroides \\
\hline
\end{tabular}

365

366

367

368 
371 Table 3. Most predominant bacterial species (abundance of more than $0.1 \%$ ) found by 372 pyrosequencing analysis of samples from 4 types of chicha. Chewed cassava (CC), mushed 373 cassava (MC), chonta $(\mathrm{CB})$ and corn $(\mathrm{CoB})$. Numbers indicate percentages and "+" indicates that 374 bacterium recovered in culture.

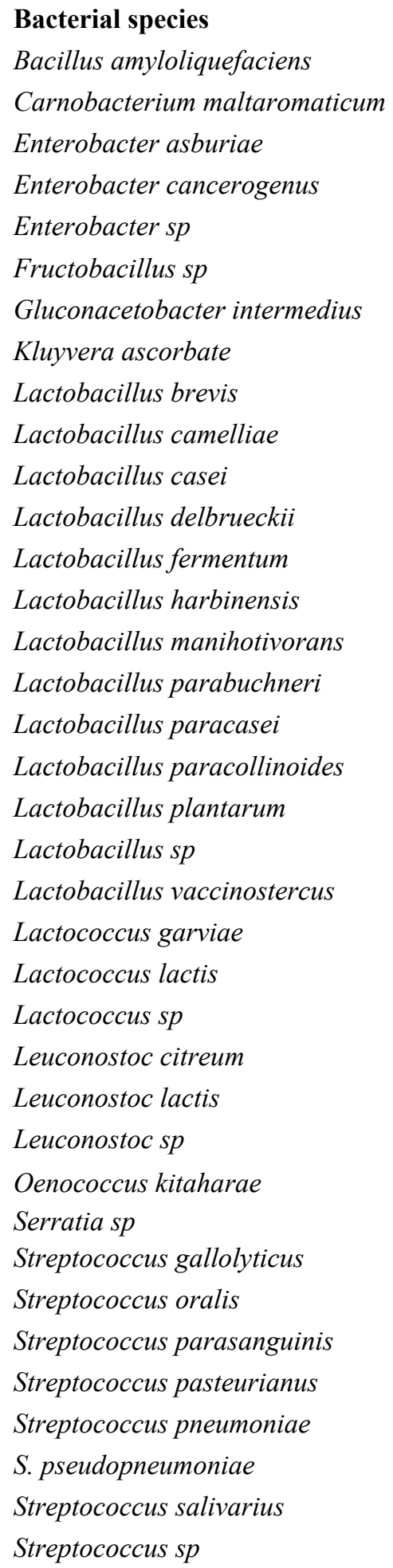

\begin{tabular}{|c|c|c|c|c|c|}
\hline $\mathrm{CC}$ & MC & CB & CoB & Cultured & Possible origins \\
\hline 0.0 & 0.5 & 0.0 & 0.00 & - & Environment \\
\hline 0.0 & 0.0 & 1.0 & 0.1 & - & Environment \\
\hline 0.5 & 0.0 & 0.0 & 0.0 & - & Environment \\
\hline 0.5 & 0.0 & 0.0 & 0.0 & - & Environment \\
\hline 1.3 & 0.0 & 0.1 & 0.0 & - & Environment \\
\hline 0.0 & 0.0 & 0.0 & 3.8 & - & Vegetables \\
\hline 0.0 & 0.0 & 0.0 & 0.6 & - & fermented food \\
\hline 0.4 & 0.0 & 0.0 & 0.0 & - & Human gut, food \\
\hline 8.4 & 0.1 & 2.5 & 0.6 & - & Environment, gut \\
\hline 0.0 & 0.0 & 0.0 & 7.3 & - & Environment, gut \\
\hline 0.0 & 0.0 & 0.0 & 3.1 & + & Environment, gut \\
\hline 8.0 & 0.0 & 0.0 & 0.0 & - & Environment, gut \\
\hline 6.5 & 3.8 & 0.0 & 0.0 & + & Environment, gut \\
\hline 0.0 & 0.0 & 0.0 & 2.1 & - & Vegetables \\
\hline 1.8 & 0.0 & 0.0 & 0.0 & - & Vegetables \\
\hline 0.0 & 0.0 & 0.0 & 1.4 & + & Oral microbiota \\
\hline 0.0 & 0.0 & 0.0 & 8.6 & + & Environment, gut \\
\hline 0.0 & 0.0 & 0.0 & 16.0 & - & Environment, gut \\
\hline 10.8 & 0.0 & 12.4 & 0.1 & + & Environment, gut \\
\hline 3.4 & 0.0 & 0.7 & 1.3 & - & Environment, gut t \\
\hline 1.2 & 0.0 & 0.2 & 0.0 & - & Environment, gut \\
\hline 0.0 & 0.0 & 2.8 & 0.0 & - & Fermented food \\
\hline 2.1 & 0.0 & 8.9 & 0.0 & + & Environment, gut \\
\hline 0.2 & 9.3 & 1.0 & 0.2 & - & Gut \\
\hline 0.0 & 1.5 & 1.2 & 0.0 & - & fermented food \\
\hline 1.7 & 0.1 & 0.2 & 0.8 & - & Environment \\
\hline 0.0 & 0.0 & 0.1 & 4.6 & - & Vegetables \\
\hline 0.0 & 0.0 & 0.0 & 1.2 & - & Vegetables \\
\hline 1.0 & 0.0 & 0.0 & 0.0 & - & Environment \\
\hline 0.0 & 0.5 & 0.0 & 0.0 & - & Oral microbiota \\
\hline 1.4 & 0.2 & 0.0 & 0.0 & - & Oral microbiota \\
\hline 5.4 & 3.5 & 0.0 & 0.0 & - & Oral microbiota \\
\hline 0.0 & 7.7 & 0.0 & 0.0 & - & Human gut \\
\hline 3.6 & 0.5 & 0.0 & 0.0 & - & Human nasopharynx \\
\hline 0.5 & 0.0 & 0.0 & 0.0 & - & Human nasopharynx \\
\hline 32.0 & 65.0 & 0.0 & 0.0 & + & Oral microbiota \\
\hline 2.5 & 2.3 & 0.1 & 0.0 & - & Human microbiota \\
\hline
\end{tabular}




Streptococcus thermophilus
Streptococcus vestibularis
Weissella cibaria
Weissella confusa
Weissella paramesenteroides
Weissella sp

Streptococcus thermophilus

$\begin{array}{llllll}1.2 & 2.59 & 0.0 & 0.0 & - & \text { Vegetables } \\ 0.4 & 0.8 & 0.0 & 0.0 & - & \text { Oral microbiota } \\ 0.1 & 0.0 & 0.9 & 0.9 & - & \text { Vegetables } \\ 0.5 & 0.1 & 45.9 & 25.3 & + & \text { Vegetables } \\ 0.5 & 0.0 & 0.1 & 0.0 & - & \text { Environment } \\ 0.2 & 0.3 & 19.8 & 19.4 & - & \text { Vegetables }\end{array}$


377 Table 4. Most predominant fungal species found by pyrosequencing analysis of samples

378 from 3 types of chicha. Chewed cassava (CC), mushed cassava (MC) and chonta (CB). The 379 numbers indicate percentages.

\begin{tabular}{lcccc}
\hline Fungal species & CC & MC & CB & Possible origins \\
\hline Saccharomyces cerevisiae & 92.533 & 92.023 & 92.033 & Vegetables \\
Penicillium citrinum & 0.03 & 0.021 & 0.062 & Soil \\
Debaryomyces hansenii & 0.636 & 0.547 & 0.549 & Sea water \\
Hanseniaspora uvarum & 0.044 & 0.056 & 0.075 & Vegetables \\
Wallemia muriae & 0.118 & 0.115 & 0.137 & Salty water \\
Wallemia sp & 1.316 & 1.701 & 1.602 & Salty water \\
Aspergillus sp & 0.089 & 0.047 & 0.032 & Soil \\
Pichia kudriavzevii & 1.05 & 1.5 & 1.32 & Vegetables \\
Aspergillus versicolor & 0.104 & 0.138 & 0.135 & Soil \\
Pichia burtonii & 0.118 & 0.123 & 0.107 & Vegetables \\
Hyphopichia burtonii & 0.089 & 0.067 & 0.073 & Starch substrates \\
Cyberlindnera sp & 0.532 & 0.54 & 0.545 & Waste deposits \\
Pichia sp & 0.044 & 0.04 & 0.054 & Soil \\
Saccharomyces bayanus & 0.104 & 0.132 & 0.096 & Vegetables \\
Galactomyces sp & 3.149 & 2.908 & 3.133 & Rumen, fermented food \\
Pichia fermentans & 0.044 & 0.042 & 0.047 & Vegetables \\
\hline
\end{tabular}


